Ks. Dariusz ZAGÓRSKI

(Toruń, UMK)

\title{
NIEROZERWALNOŚĆ MAŁŻEŃSTWA W MYŚLI JANA CHRYZOSTOMA
}

Nauczanie Jana Chryzostoma odnoszące się do zagadnienia nierozerwalności małżeństwa „wiąże się z tekstem Księgi Rodzaju (Rdz 2, 24), przytaczanym przez ewangelistę Mateusza (Mt 19, 5-6)" i Listem św. Pawła Apostoła do Efezjan (Ef 5, 31). Słowa zawarte w Genesis nasz Autor uznaje za uzasadnienie trwałości i nierozdzielności związku małżeńskiego. Wskazują one bowiem na głęboką jedność, która od początku panować miała między mężczyzną i kobietą, wpisaną w pierwotny zamiar stwórczego dzieła Boga ${ }^{2}$.

$\mathrm{W}$ formułowaniu wykładu na temat małżeństwa i jego nierozerwalności, wielką wagę posiada właściwe naświetlenie przez Antiocheńczyka zagadnienia grzechu cudzołóstwa, stanowiącego zagrożenie trwałości związku, którego pojęcie - skażone panującą w świecie pogańskim, ale także w środowisku chrześcijan z Antiochii jednostronnością, dyskryminowało w sposób rażący kobietę, wyzwalając spod odpowiedzialności za nierozerwalność wspólnoty małżeńskiej- mężczyznę. Znaczące miejsce zajmują również Chryzostomowe wyjaśnienia starotestamentowej zasady autorstwa Mojżesza, dopuszczającej wręczenie żonie listu rozwodowego i oddalenie jej, która skonfrontowana zostaje przez naszego Autora z przesłaniem Chrystusa o trwałości i nierozerwalności małżeństwa.

\section{JEDNOŚĆ ZAŚLUBIONYCH FUNDAMENTEM NIEROZERWALNOŚCI MAŁŻEŃSTWA}

W homilii 20 na List do Efezjan Jan Chryzostom akcentuje wielką troskę Boga, okazaną człowiekowi w tym, że ustanowił On związek małżeński. Z postanowienia Stwórcy miała się w nim objawiać i panować wyjątkowa łączność między dwojgiem ludzi, przewyższająca wszelkie inne relacje i zażyłości:

${ }^{1}$ J. Krykowski, Nauka o matżeństwie, rodzinie i wychowaniu (Wstęp), w: Św. Jan Chryzostom, O matzeństwie, wychowaniu dzieci i ascezie (Wybór tekstów), tłum. W. Kania - L. Małunowiczówna - K. Bielawski - M. Jurek - J. Sawicka, oprac. J. Naumowicz, BOK 19, Kraków 2002, 25.

${ }^{2}$ Por. tamże, s. 29. 
„Pismo mówi o dwojgu jak o jednym: «Stworzył mężczyznę i niewiastę» (Rdz 1, 27). I w innym miejscu: «Nie ma już mężczyzny ani kobiety» (Ga $3,28)$. Nie może bowiem istnieć taka więź między przyjaciółmi, jak między kobietą i mężczyzną, którzy są połączeni prawym węzłem małżeńskim. Dlatego błogosławiony mąż, chcąc okazać ogromną miłość, gdy opłakiwał swego przyjaciela, nie wspomina o ojcu, ani matce, ani dziecku, ani bracie, ani przyjacielu, ale mówi: «Twoja miłość znaczyła dla mnie więcej niż miłość kobiet» (2 Sm 1, 26). Rzeczywiście miłość ta jest mocniejsza od każdej władzy. Inne uczucia są bowiem gwałtowne, to zaś jest nie tylko gwałtowne, ale i nieugaszalne. Tkwi bowiem w naturze jakaś ukryta siła i w tajemniczy sposób skłania ku sobie nasze ciała"’.

Wspomniana jedność osób zaślubionych wypływa, zdaniem naszego Autora, z faktu, że początek istnienia niewiasty odnajdywany jest w mężczyźnie, z którego została ona utworzona. Takie zrządzenie Stwórcy akcentuje wyjątkową więź małżonków i szczególne ich pokrewieństwo:

„Na początku kobieta została utworzona z mężczyzny, a potem ze związku tych dwojga rodzi się mężczyzna bądź kobieta. Czy widzisz, o jaką więź i pokrewieństwo chodzi, i jak Bóg nie pozwolił wtargnąć tu obcej substancji? Zobacz, jak dobrze zarządził. Dopuścił, aby człowiek poślubił już nie swoją siostrę, ale bardziej niż siostrę, córkę, a nawet już nie córkę, bo coś więcej niż córkę - własne ciało"4.

Wyrażenie: „własne ciało” staje się istotnym dla Jana Chryzostoma w zachętach kierowanych do mężów, by obdarzali oni swe żony wyjątkową miłością - taką, jaką człowiek obdarowuje swoje ciało, gdy je żywi i pielęgnuje. Jest to zdaniem naszego Autora znaczące porównanie, które wyraźnie określa nakaz miłości względem małżonki. W świetle bowiem takiej paraleli miłość nie jest już tylko „kwestią dowolności”, lecz obowiązku i konieczności. Te wskazania naszego Autora ponownie - w dobitny sposób - podkreślają jedność związku małżeńskiego i jego trwałość:

„I gdy powiedział [Apostoł]: «[mężowie powinni kochać swoje żony] jak własne ciało» (Ef 5, 28), dodaje: «Przecież nikt nigdy nie nienawidził własnego ciała, ale każdy żywi je i pielęgnuje» (Ef 5, 29). To znaczy: odnosi się do niego $\mathrm{z}$ wielką troską. A jakie jest jego ciało? Posłuchaj: «Ta dopiero jest kością z moich kości - mówi - i ciałem z mojego ciała» (Rdz 2, 29). Posłuchaj również tych słów: «I będą jednym ciałem» (Rdz 2, 24)"s.

Ów nakaz miłości, do którego zobowiązany został w sposób szczególny mężczyzna sprzyjać ma podtrzymywaniu jedności i szczęśliwości małżeństwa.

\footnotetext{
${ }^{3}$ In epistulam ad Ephesios hom. 20, 1, PG 62, 135, thum. M. Jurek, BOK 19, 47-48.

${ }^{4}$ Tamże, BOK 19, 48.

${ }^{5}$ Tamże 20, 3, PG 62, 139, BOK 19, 53.
} 
Obowiązkiem nałożonym na kobietę przez Pismo Święte jest cześć, jaką winna okazywać współmałżonkowi i bojaźń względem niego ${ }^{6}$. Idealnym jednak węzłem unifikującym zaślubionych jest wzajemna miłość - braku jej bowiem nie zrekompensuje jedynie poddanie płynące ze strachu:

„Ale gdy żona oddaje ci cześć, zawsze domagaj się, aby była to cześć, jaka pochodzi od wolnej kobiety. Nie jak od niewolnicy! [...] Na czym ta cześć ma polegać? Aby nie sprzeciwiać się, nie występować przeciw mężowi, nie pragnąć pierwszeństwa. Do tego wystarczy sama cześć. A jeśli kochasz, kobieto, jak zostałaś do tego zobowiązana, będziesz czynić więcej. I już nie ze strachu, ale sama miłość będzie tu działać"

Jedność, będąca celem i centrum Chryzostomowej wizji życia małżeńskie$\mathrm{go}^{8}$, odnajduje swe uzasadnienie również w ,mistycznej jedności Chrystusa z Kościołem. Małżeństwo jest typem tej jedności, która jest realna, ścisła, wyłączna i trwała aż do końca czasów".

Jedność małżonków w świetle tajemnicy jedności Chrystusa i Kościoła, uzyskuje niejako wymiar ponadnaturalny i staje się częścią planu BogaStwórcy. Jan Chryzostom posługując się terminologią Pawłową nazywa ową relację małżeńskiej bliskości i zjednoczenia „misterium” i „tajemnicą”, ${ }^{10}$ i tłumaczy znaczenie oraz sens tych nazwań:

„I dlatego Apostoł dodaje: «Tajemnica to wielka, ja zaś mówię w odniesieniu do Chrystusa i Kościoła» (Ef 5, 32). Co to znaczy? Mówi on, że jest to wielka tajemnica. Już błogosławiony Mojżesz, a raczej sam Bóg dał do zrozumienia, że to coś wielkiego i godnego podziwu. Teraz zaś czytamy: «W odniesieniu do Chrystusa mówię». Ponieważ i On opuścił Ojca, zstąpił i przyszedł do Oblubienicy, i stał się z nią jednym duchem. «Ten kto łączy się z Panem, jest z Nim jednym duchem» (1Kor 6, 17). I słusznie Apostoł powiedział: «Wielka to tajemnica». Jakby chciał przez to powiedzieć: To porównanie nie zaprzecza miłości. «Niech także każdy z was tak miłuje swoją żonę jak siebie samego. A żona niech się odnosi ze czcią do swojego męża» (Ef 5, 33). Rzeczywiście, jest to tajemnica i to wielka, że syn opuszcza ojca, który przekazał mu życie,

\footnotetext{
${ }^{6}$ Jan Chryzostom zwraca uwagę na równą godność mężczyzny i kobiety. Za św. Pawłem uznaje jednak podporządkowanie kobiety mężowi, por. R.A. Krupp, Shepherding the Flock of God. The Pastoral Theology of John Chrysostom, New York 1991, 173.

${ }^{7}$ In epistulam ad Ephesios hom. 20, 5, PG 62, 142, BOK 19, 59; por. także tamże 20, 5, PG 62 , 141, BOK 19, 57: „Zgoda zaś między nimi (małżonkami) będzie trudna i bolesna, jeśli nie złączy ich potęga miłości. Braku miłości na pewno nie naprawi strach”.

${ }^{8}$ Por. Krykowski, Nauka o matżeństwie, s. 28.

${ }^{9}$ Tamże, s. 25; por. także: G. Astruc-Morize, Saint Jean Chrysostome, théologien, moraliste et mystique, w: „, Que tous soient un”! Mélanges offerts en hommage par la Fraternité Saint-Élie à son Éminence le Métropolite de Silyvria Emilianos Timiadis, Iaşi 2005, 75.

${ }^{10}$ Określenia te służyć mają wyeksponowaniu małżeństwa chrześcijańskiego i zdystansowaniu go od pogańskich zwyczajów wiążących się z zaślubinami.
} 
opuszcza matkę, która go urodziła i ponosiła ciężary wychowania. Opuszcza rodziców, z którymi jest $\mathrm{w}$ zażyłości, a łączy się z tą, której wcześniej nie widział i która nie miała z nim nic wspólnego. I ona znaczy dla niego więcej niż wszystko [...]. Istotnie wielka to tajemnica, zawierająca niewypowiedzianą mądrość. To na początku przepowiedział Mojżesz. Tę prawdę głosi teraz Paweł: «W odniesieniu do Chrystusa i do Kościoła»"

Powyższy passus przywołuje kolejne istotne zagadnienie, które omówić należy w związku z tematem jedności, jaka panuje między dwojgiem ludzi w ramach związku małżeńskiego. Jan Chryzostom owo zespolenie (nawiązujące do Tajemnicy Chrystusa i Kościoła) opisuje poprzez Pawłowy schemat: głowa-ciało (Ef 5, 23. 28), opierając się na tradycyjnym modelu małżeństwa, podporządkowującym niewiastę mężczyźnie ${ }^{12}$. W związku małżeńskim to on jest głową, ona zaś ciałem. Funkcje te jednak wzajemnie się uzupełniają tak, że efektem jest właśnie owa nadzwyczajnie ,wiążąca” jedność:

„Kobieta zajmuje drugie miejsce. Niech więc ani ona nie domaga się równej czci - podlega bowiem głowie - ani on niech nie gardzi nią jako poddaną jest bowiem ciałem. Gdyby głowa gardziła ciałem, sama by zginęła. Niech mąż okazuje tyle miłości, ile żąda posłuszeństwa. Na podobieństwo głowy i ciała. Ono oddaje jej na służbę ręce, nogi i wszystkie pozostałe członki, ona zaś, jednocząca w sobie wszystkie zmysły, o nie się troszczy. Nie ma nic lepszego od takiego związku"'13.

\section{GRZECH CUDZOŁÓSTWA ZAGROŻENIEM TRWAŁOŚCI ZWIĄZKU}

Pierwsza część niniejszego opracowania miała na celu prezentację wykładu Jana Chryzostoma, wskazującego na fundament doktryny o nierozerwalności związku małżeńskiego, odnajdywany w natchnionych słowach Pisma Świętego. Była nim wypowiedziana przez samego Stwórcę prawda o doskonałej jedności, jaka panuje między zaślubionymi w ramach związku małżeńskiego, nawiązująca do Tajemnicy relacji zachodzącej między Chrystusem a Kościołem. Obecnie należy wskazać na nauczanie Autora odnoszące się do kwestii cudzołóstwa, stanowiącego zagrożenie nierozerwalności ustanowionej przez Boga wspólnoty. K. Tsouros dostrzega u Chryzostoma w formułowaniu jego myśli na ten temat pewną ewolucję: zauważa on, że w niektórych swych dziełach Złotousty wypowiadał się w sposób zdecydowany za nierozerwalno-

${ }^{11}$ In epistulam ad Ephesios hom. 20, 4, PG 62, 140, BOK 19, 55-56.

${ }^{12}$ Por. Krykowski, Nauka o matżeństwie, s. 27; zob. także C. Militello, Donna e Chiesa. La testimonianza di Giovanni Crisostomo, Palermo 1985, 177-178; P. Rentinck, La cura pastorale in Antiochia nel IV secolo, Roma 1970, 275.

${ }^{13}$ In epistulam ad Ephesios hom. 20, 4, PG 62, 140-141, BOK 19, 56. 
ścią związku małżeńskiego, natomiast w dziełach z późniejszego okresu swej twórczości jaśniej i obszerniej mówił o możliwości rozwiązania tego związku - jednak tylko i wyłącznie w przypadku grzechu niewierności ${ }^{14}$.

W świecie pogańskim, a także w mentalności wielu chrześcijan, grzech cudzołóstwa postrzegany był jako „bardzo poważne wykroczenie (kobiety D. Z.) przeciw małżeństwu i mężowi" ${ }^{15}$. To samo przewinienie jednak, którego dopuszczał się trwający w związku małżeńskim mężczyzna - traktowane było w prawie rzymskim bardzo liberalnie i nie niosło ze sobą żadnych konsekwencji. „Obowiązujące wówczas prawo pozwalało mężczyznom na kontakty seksualne z niewolnicami, a opinia społeczna tolerowała taki stan rzeczy" Nasz Autor uznawał równość kobiet i mężczyzn w tym względzie i wskazywał na konieczność jednakowego traktowania ich wykroczeń:

„Nie lekceważę faktu, iż wielu uważa, że do cudzołóstwa doszło tylko wtedy, gdy ktoś zdołał zdeprawować kobietę złączoną już węzłem małżeńskim z [innym] mężczyzną. Ja natomiast sądzę, że popełnia się cudzołóstwo za każdym razem, gdy mężczyzna żonaty łączy się w akcie fizycznego zjednoczenia, nieprawowitego i lubieżnego, tak z wulgarną prostytutką, jak też służącą, czy jakąkolwiek kobietą niezamężną"

Także w innym miejscu Antiocheńczyk zwraca uwagę słuchaczy na to ważne zagadnienie, wskazując, że cudzołóstwo pociąga za sobą tożsamą winę zarówno w wypadku mężczyzny, jak i kobiety ${ }^{18}$ :

„Powiedz mi więc, dlaczego karzesz swoją żonę, jeśli ona dopuściła się flirtu z osobnikiem wolnym i nieżonatym? Właśnie dlatego, że jest to cudzołóstwo

${ }^{14}$ Por. K. Tsouros, La dottrina del matrimonio in S. Giovanni Crisostomo, „Asprenas” 21 (1974) 26-27: „Nella formulazione del suo pensiero sul matrimonio e sulla separazione, per adulterio, osserviamo una certa evoluzione. Nella sua opera De Virginitate (scritta l'anno 382) come anche nel Libellum repudii, tende ad escludere ogni causa di scioglimento del matrimonio, mentre, nelle opere posteriori, quali: De decem millium talenti debitore (scritta l'anno 387), Adversus eos qui Judaeorum jejunium (scritta in tempo incerto in Antiochia), e nei suoi commenti alle epistole di Paolo ai Corinzi (scritte l'anno 392), si esprime chiaramente e con maggiore ampiezza sulla possibilità di scioglimento del matrimonio, però, solo in caso di adulterio".

${ }^{15}$ Por. P. Szczur, Problematyka spoteczna w późnoantycznej Antiochii na podstawie nauczania homiletycznego Jana Chryzostoma, Lublin 2008, 337.

16 Tamże.

${ }^{17}$ In illud: „Propter fornicationes unusquisque suam uxorem habeat” 4, PG 51, 213 (thum. własne).

${ }^{18}$ Por. L. Dattrino, Il matrimonio nel pensiero di San Giovanni Crisostomo, Roma 2002, 102; Rentinck, La cura pastorale, s. 270. Chryzostom w kontekście cudzołóstwa krytyce poddawał także obecność mężczyzn na spektaklach teatralnych, gdzie dochodziło do znieważania i ośmieszania instytucji małżeństwa i jego świętości, zob. S. Zincone, Aspetti del raporto uomo-donna nelle Omelie di Giovanni Crisostomo sul Vangelo di Matteo, w: „Historiam perscrutari”. Miscellanea offerti al prof. O. Pasquato, red. M. Maritano, Roma 2002, 863. 
[...]. Lecz także i ty związany jesteś ze swą żoną. Stąd to, czego ty się dopuszczasz jest cudzołóstwem w równej mierze"19.

Homilie na Ewangelię wedtug św. Mateusza, które Chryzostom wygłosił w Antiochii prawdopodobnie w latach 390/391, zdają się potwierdzać tezę Tsourosa o deklarowanej przez naszego Autora (w późniejszych swych dziełach), możliwości rozwiązania wspólnoty małżeńskiej w przypadku cudzołóstwa $^{20}$. I chociaż nasz Autor wypowiada ową prawdę kilkakrotnie, mając być może na względzie dobro strony pokrzywdzonej, która nie chce dalej tolerować rozwiązłości niszczącej wspólne pożycie (stanowiłoby to bowiem swoiste przyzwolenie na grzech cudzołóstwa), to jednak wyraźnie staje on po stronie nierozerwalności związku, chociażby przez wskazania dalszych niebezpieczeństw po jego rozpadzie i rozłączeniu wspólnoty życia.

Rozwód bowiem - zdaniem Złotoustego - naraża obu małżonków na powielanie grzechu cudzołóstwa i kładzie na barki odpowiedzialność za dalsze życie współmałżonka:

„Widzisz, jak wszędzie zwraca się [Jezus - D. Z.] do mężczyzn: «Każdy, powiada, kto oddala swoją żonę - poza wypadkiem nierządu - naraża ją na cudzołóstwo» (Mt 5, 32). Taki człowiek, choćby nie pojął innej, stał się winny grzechu dlatego, że skłonił ją do cudzołóstwa. Nie mów mi, że on ją opuścił, bo nawet opuszczona pozostaje żoną tego, który ją opuścił. Potem, by nie zrzucać wszystkiego na tego, który opuszcza, i nie czynić żony zarozumialszą, zamknął i jej drzwi do tego, kto by ją pojął, mówiąc: «A kto by oddaloną wziął za żonę, dopuszcza się cudzołóstwa»" "21.

Jan Chryzostom ukazując wzniosłość małżeństwa i broniąc jego nierozerwalność podsuwa swym słuchaczom bardzo konkretne wskazania i zachęty. Trwałość małżeństwa bowiem nie jest zależna jedynie od współmałżonków. Troska o nią winna leżeć na sercu wszystkim wiernym. Zachęca więc Antiocheńczyk do porzucenia pożądliwości, która, jak dzikie zwierzę, niszczy pokój serca i zniewala. Ona też staje się niejako zewnętrznym zagrożeniem dla związków małżeńskich, których rozpad często bierze swój początek w nieuporządkowanym pragnieniu cudzych żon ${ }^{22}$ :

${ }^{19}$ In epistulam I ad Thessalonicenses hom. 5, 2, PG 62, 425 (tłum. własne).

${ }^{20}$ Wcześniej przywołane w tekście ,równouprawnienie” wobec odpowiedzialności każdego ze współmałżonków za grzech cudzołóstwa znajduje swe odzwierciedlenie we wszystkich nakazach i pouczeniach Chryzostoma. Stwierdza on, że „wszędzie daje (Chrystus - D. Z.) wspólne prawa: mówiąc do głowy, daje też upomnienie dla całego ciała. Kobietę i mężczyznę uważa za to samo stworzenie i nigdzie nie rozróżnia rodzaju”, por. In Matthaeum hom. 17, 2, PG 57, 257, tłum. J. Krystyniacki, ŹMT 18, 217.

${ }^{21}$ In Matthaeum hom. 17, 4, PG 57, 259, ŹMT 18, 219-220.

${ }^{22}$ Por. Rentinck, La cura pastorale, s. 268-269. 
„A gdy chcesz spoglądać i doznawać w tym przyjemności, to spoglądaj na swą żonę i kochaj ją zawsze: tego nie zabrania ci żadne prawo. A jeśli chcesz zajmować się obcą pięknością, wtedy obrażasz zarówno żonę, zwracając swe oczy gdzie indziej, jak i tę, którą dotykasz. Nawet jeśli nie dotknąłeś jej ręką, dotknąłeś oczyma. Dlatego również to uważane jest za cudzołóstwo i sprowadza niezwykłą karę [jeszcze] przed karą na tamtym świecie. Napełnia całe wnętrze człowieka niepokojem i zamieszaniem, powstaje w ten sposób wielka burza, bardzo silny ból, a ten, kto go doznał, będzie w nie lepszym położeniu, niż jeńcy i więźniowie. Kobieta natomiast, rzuciwszy pocisk, często ulatnia się, rana zaś mimo to pozostaje. A nawet przeciwnie, nie ona rzuciła pocisk, lecz ty sam zadałeś sobie śmiertelną ranę, patrząc pożądliwie"23.

Podsumowaniem tych wywodów staje się przedstawiony przez Chryzostoma schemat, obrazujący znaczącą zależność nierozerwalności pożycia małżeńskiego od powściągliwości każdego człowieka:

„Czy widzisz, jak to wszystko zmierza do wyższego celu? Kto nie będzie spoglądać pożądliwym okiem na cudzą żonę, ten nie będzie cudzołożyć; gdy zaś nie będzie cudzołożyć, wtedy nie da mężowi powodu do opuszczenia swej żony"24.

\section{NIEROZERWALNOŚĆ MAŁŻEŃSTWA W ŚWIETLE ZGODNOŚCI CHRYSTUSOWYCH NAKAZÓW ZE STAROTESTAMENTALNYM PRAWEM}

W Homilii 17 na Ewangelię wedtug św. Mateusza Jan Chryzostom, komentując perykopę Mt 5, 31, przywołuje zagadnienie listu rozwodowego, który - na podstawie prawa Starego Testamentu, wydanego przez Mojżesza - mężczyzna mógł wręczyć swej żonie i oddalić ją. Antiocheńczyk w swym komentarzu pragnie wyjaśnić ów temat, wzbudzający z pewnością wśród wiernych wiele wątpliwości i pytań, nade wszystko w kontekście przekazu Ewangelicznego, to jest Chrystusowego nauczania ${ }^{25}$.

Nasz Autor przypomina, że prawo to pozwalało mężczyźnie opuścić swą żonę wtedy, gdy ten, z jakiegokolwiek powodu ją znienawidził, i dozwalało również wejść w związek małżeński z inną. Złotousty Kaznodzieja wskazuje jednak na takie prawne obwarowania, które obligowały stronę oddalającą do zachowania pewnych procedur. Chodziło o wręczenie wyżej wspomnianego listu rozwodowego, co nadawało sprawie charakteru urzędowego i wspólnotowego, wyłączając ją ze sfery jedynie prywatnych rozstrzygnięć:

${ }^{23}$ In Matthaeum hom. 17, 2, PG 57, 257, ŹMT 18, 216-217.

${ }^{24}$ Tamże 17, 4, PG 57, 260, ŹMT 18, 220.

25 Por. Szczur, Problematyka społeczna, s. 296; zob. także: A. Młotek, Nierozerwalność matzeństwa w nauczaniu Ojców Kościoła, CS 10 (1978) 182-183. 
„Istniało dawne prawo, które każdemu, kto z jakiejkolwiek bądź przyczyny znienawidziłby swoją żonę, pozwalało ją opuścić i nie zabraniało pojąć zamiast niej innej. Jednakże prawo nie pozwalało czynić tego w sposób jedynie prywatny, ale nakazywało wręczyć żonie list rozwodowy, tak że nie było w jej mocy wrócić do niego, aby zachować choć pozór małżeństwa. Gdyby nie nakazał tego, lecz byłoby wolno rozłączyć się z jedną, a pojąć drugą, a potem znowu połączyć się z pierwszą, wyniknęłoby stąd wielkie zamieszanie, gdyż wszyscy ciągle braliby sobie żony innych i byłoby to oczywistym cudzołóstwem. Dlatego list rozwodowy przyniósł niemałe pociechy”26.

Po omówieniu ,funkcji” listu rozwodowego nasz Autor stara się ukazać wiernym cel, który przyświecał Prawodawcy przy ustalaniu omawianego przepisu. Jest nim troska o kobietę, która pozostając dalej w domu swego męża mogła być narażona na wielkie niebezpieczeństwo, z utratą życia włącznie:

„Dozwolił na to [Prawodawca] dla uniknięcia innego, o wiele większego występku. Gdyby nakazał zatrzymać w domu żonę, choćby znienawidzoną, wtedy mąż, który jej nienawidził, zabiłby ją. Taki właśnie był naród żydowski. Ci, którzy nie przebaczali swym dzieciom, zabijali proroków i przelewali krew jak wodę, tym bardziej nie przepuszczaliby własnym żonom. Dlatego przyzwolił na mniejsze [zło], by zapobiec większemu"27.

Do tematu listu rozwodowego Jan Chryzostom powraca jeszcze w Homilii 62 na Ewangelię wedtug św. Mateusza, komentując fragment Mt 19, 3-9. Ów passus bowiem w szczególny sposób ukazuje wykład samego Zbawiciela o nierozerwalności małżeństwa przeprowadzony w kontekście pytań faryzeuszy powołujących się na to właśnie starotestamentalne Prawo. Nasz Autor obszernie relacjonuje dialog Zbawiciela ze swymi adwersarzami, akcentując najpierw ich złość i przebiegłość w atakach przypuszczanych przeciw Chrystusowi:

„Zwróć uwagę na złość zawartą w sposobie postawienia przez nich pytania. Nie powiedzieli do Niego: «Kazałeś nie opuszczać żony», choć już mówił o tym prawie (por. Mt 5, 31-32). Jednakże nie przypomnieli Jego słów, lecz tak zaczęli. Sądząc, że zastawią większą pułapkę i chcąc Go koniecznie zmusić do oświadczenia się przeciwko Prawu, nie mówią: «Czemu ustanowiłeś to a to?», ale pytają, jakby nic nie mówił: «Czy wolno?» (Mt 19, 3), myśląc, że zapomniał, co powiedział. W razie gdyby odpowiedział, że wolno [ją] opuścić, byli gotowi powołać się na Jego własne słowa i powiedzieć: «Czemu mówisz rzeczy sprzeczne?» Gdyby zaś powiedział to samo, co przedtem, powołaliby się na Mojżesza"28.

\footnotetext{
${ }^{26}$ In Matthaeum hom. 17, 4, PG 57, 259, ŹMT 18, 219.

${ }^{27}$ Tamże.

${ }^{28}$ Tamże 62, 1, PG 58, 596-597, ŹMT 23, 246.
} 
Antiocheńczyk poddaje także wnikliwej analizie postawę samego Zbawiciela. Podkreśla Jego przenikliwość i mądrość, a także błyskotliwość w stosowanej argumentacji. Wszystko po to, by ukazać wiernym, jak ważny jest wykład Pana, dla uzgodnień nowych przykazań ze starotestamentalnym Prawem ${ }^{29}$ :

„Jakąż̇ więc daje odpowiedź [Zbawiciel faryzeuszom - D. Z.]? «Czy nie czytaliście, że Twórca od początku uczynił ich mężczyzną i kobietą?» (Rdz 1, 27; 5, 2) I rzekł: «Dlatego opuści człowiek ojca i matkę i złączy się ze swoją żoną, i będą oboje w jednym ciele» (por. Rdz 2, 24; Ef 5, 31). «A tak już nie są dwoje, lecz jedno ciało. Co więc Bóg złączył, człowiek niech nie rozdziela» (Mt 19, 6)"30.

Jak wynika z powyższego passusu, zharmonizowanie przez Chrystusa starego Prawa z nowym, mające na celu wyeksponowanie istotnej tezy Jego nauczania - prawdy o nierozerwalności małżeństwa - dokonuje się najpierw w oparciu o niepodważalne fakty - to jest stwórcze działanie Boga i Jego słowne nakazy:

„Zauważ, że stwierdza to nie tylko na podstawie faktu stworzenia, lecz także na podstawie Jego rozporządzenia. Nie tylko powiedział, że uczynił jednego mężczyznę i jedną kobietę, ale także to, że przykazał, aby jeden mężczyzna złączył się z jedną kobietą. Gdyby zaś chciał, żeby opuścił żonę i wziął sobie inną, (wówczas uczyniwszy jednego mężczyznę), ukształtowałby wiele kobiet. Tak nawet przez sposób stworzenia i przez sposób nadania prawa [wskazał - D. Z.], że jeden mężczyzna winien być zawsze złączony z jedną kobietą i nigdy się z nią nie rozłączać"’31.

Następnie Złotousty wskazuje na kolejny przejaw zgodności, jaka zachodzi między wskazaniami starotestamentalnymi a słowami Chrystusa. Pan bowiem, uzasadniwszy ścisłą jedność małżonków, a także nierozerwalność ich wspólnoty w świetle starego Prawa, sam tworzy nowe normy i wprowadza je w życie, powołując się jednak w dalszym ciągu na wcześniejsze ustanowienia:

„Skoro przytoczył stare Prawo, które zostało ustanowione czynem i słowem, oraz dowiódł jego wiarygodności osobą Prawodawcy, objaśnia je własną mocą i nadaje prawo mówiąc: «A tak już nie są dwoje, lecz jedno ciało» (Mt 19, 6) [...]. Nie poprzestał jednak na tym, lecz powołał się na Boga, mówiąc: «Co Bóg złączył, niech człowiek nie rozdziela», dowodząc, że taki czyn jest wbrew naturze i prawu"32.

${ }^{29}$ Tamże 62, 2, PG 58, 597, ŹMT 23, 247.

${ }^{30}$ Tamże 62, 1, PG 58, 597, ŹMT 23, 246.

${ }^{31}$ Tamże 62, 1, PG 58, 597, ŹMT 23, 246-247.

32 Tamże 62, 2, PG 58, 597, ŹMT 23, 247; por. Szczur, Problematyka społeczna, s. 297; Rentinck, La cura pastorale, s. 270-271. 
Antiocheńczyk zauważa jednak, że powyższe objaśnienia Chrystusa nie zadowoliły faryzeuszy, którzy dostrzegając rozdźwięk między Jego wykładem a tym, czego nauczał Patriarcha Mojżesz, dalej brnęli w ataku na Zbawiciela, zadając $\mathrm{Mu}$ wprost pytanie o Mojżeszowy list rozwodowy i cel jego ustanowienia ${ }^{33}$. Chrystusowa odpowiedź jest jednoznaczna: broni ona Mojżesza, który przecież pod natchnieniem Boga sformułował to prawo. Stawia jednak zarzuty swym przeciwnikom i jako powód wprowadzenia normy podaje zatwardziałość ludzkiego serca:

„«Mojżesz przez, wzgląd na zatwardziałość waszych serc takie prawo ustanowił» (Mt 19,8). Nie pozwala, by Mojżesz pozostawał pod zarzutem, bo to On sam nadał mu to prawo, lecz uwalnia go od zarzutu, a całą winę zrzuca na nich, jak to czyni w każdym innym przypadku. Gdy stawiali Jego uczniom zarzuty, że rwali kłosy, dowodzi, że to właśnie [zarzucający] są winni (por. Mt 12, 1-8); gdy powstawali przeciwko nim za nieumywanie rąk, wykazuje, że to oni łamią prawo (por. Mt 15, 1-20); podobnie czyni w sprawie szabatu (por. Mt 12, 1-8. 9-14) oraz przy każdej innej okazji, także tu"34.

Antiocheńczyk w bardzo czytelny sposób wyjaśnił swym słuchaczom pozorne sprzeczności, jakie zdawały się zachodzić między starotestamentalnym Prawem a przykazaniami wprowadzanymi przez Zbawiciela $\mathrm{w}$ odniesieniu do nauki o związku małżeńskim i jego nierozerwalności. Z całą pewnością miało to wzmocnić przekonanie wiernych o świętości wspólnoty dwojga ludzi i jej trwałości.

Nierozerwalność małżeństwa w myśli Jana Chryzostoma bazuje na fundamencie, jakim jest jedność małżonków, bardzo silna i niepodważalna, która wynika ze stwórczego aktu Boga i Jego ustanowienia. Jedność ta odnajduje swe uzasadnienie także w mistycznej jedności Chrystusa i Kościoła, co jeszcze wyraźniej wskazuje na trwałość wspólnoty życia dwojga ludzi połączonych węzłem małżeńskim. Antiocheńczyk zgodnie z nauczaniem Pisma Świętego dostrzega jednak niebezpieczeństwa grożące owej jedności i czyhające na nierozerwalność związku: są nimi grzechy pożądliwości i nieuporządkowanych pragnień prowadzące do zła cudzołóstwa, a więc grzechu małżeńskiej niewierności.

Tezę o nierozerwalności małżeństwa potwierdza sam Chrystus, który w swym nauczaniu ukazuje zgodność pozornie sprzecznych wykładów Starego i Nowego Prawa. Znaczenie Chrystusowego autorytetu w argumentacji skierowanej do chrześcijan, miało zapewne wzmocnić w wiernych odpo-

\footnotetext{
${ }^{33}$ Por. In Matthaeum hom. 62, 2, PG 58, 598, ŹMT 23, 247.

${ }^{34}$ Tamże, ŹMT 23, 248.
} 
wiedzialność za wspólnotę dwojga ludzi i troskę wszystkich - nie tylko małżonków - o jej nierozerwalność. Słowa Zbawiciela miały także zaakcentować aktualność tejże tematyki i jej ponadczasowe znaczenie.

\section{THE INSEPARABILITY OF MARRIAGE IN THE THOUGHTS OF ST. JOHN CHRYSOSTOM}

\section{(Summary)}

The inseparability of marriage in the thoughts of St. John Chrysostom has its base on the fundament of that which is the unification of the spouses, very strong and undisputable, which is a result of the creation act of God and of His establishing. That unity finds its justification also in the mystical unification of Christ and the Church, which even more so points to the lastingness of the communion of the lives of two people joined together by the ties of marriage.

The Antiochian, in accordance with the teachings of the Holy Scriptures is aware though of the dangers which are threatening that unity and seeking to undermine the inseparability of the union. They are the sins of lust and the disordered longings which lead to the evil of adultery, and therefore the sin of marital infidelity.

This thesis on the inseparability of marriage is confirmed by Christ Himself, who in his teaching shows the agreement, of the initially seemingly to be in disagreement, teachings of the Old and New Law. The meaning of the Christological authority in this argument directed towards Christians was surely meant to strengthen in the faithful the responsibility for the communion of two persons and the care of all - not only spouses - for its inseparability. The words of the Savior also were to accent the actuality of this subject and its timeless meaning. 
